\title{
EFFECT OF DIFFERENT SOWING DATES ON SOME COTTON (Gossypium hirsutum L.) VARIETIES UNDER THE SECOND CROP GROWING CONDITIONS
}

\author{
COPUR, O. ${ }^{*}{ }^{*}$ POLAT, D. ${ }^{2}-$ OdABASIOĞLU, C. ${ }^{1}-$ HALILOGLU, H. ${ }^{1}$ \\ ${ }^{I}$ Department of Field Crops, Faculty of Agriculture, Harran University, 63190 Sanliurfa, \\ Turkey \\ ${ }^{2}$ Department of Field Crops, Graduate School of Natural and Applied Sciences, Harran \\ University, 63190 Sanliurfa, Turkey \\ *Corresponding author \\ e-mail: ocopur@harran.edu.tr; phone: +90-414-318-3690
}

(Received $16^{\text {th }}$ Jul 2019; accepted $15^{\text {th }}$ Nov 2019)

\begin{abstract}
Determining the genotypic effect on yield and fiber quality of cotton grown especially as a second crop is an important production strategy in some regions. The aim of this study was to determine the effects of different planting dates on cotton grown as second crop under the ecological conditions of the Harran Plain in Sanliurfa Turkey. The experiment was conducted on the experimental area of Agricultural Faculty of Harran University at Eyyubiye Campus in 2014 and 2015 growing seasons. Seeds of cotton cultivars were sown at different sowing dates with the randomized complete block design using split plot experimental design with three replications. Sowing dates $\left(1^{\text {th }}\right.$ of June, $10^{\text {th }}$ of June and $20^{\text {th }}$ of June) were arranged as main plots and four cotton (Stoneville 468, BA 119, DP 499 and PG 2018) varieties were distributed to sub plots size of $2.8 \mathrm{~m} \times 10 \mathrm{~m}$ and row spacing and intra-row spacing of $70 \mathrm{~cm}$ and $15 \mathrm{~cm}$, respectively. Results indicated that seed cotton yields varied between $1440 \mathrm{~kg} \mathrm{ha}^{-1}$ and $4560 \mathrm{~kg} \mathrm{ha}^{-1}$ in this study and that the most suitable planting date was June $1^{\text {st }}$ to June $10^{\text {th }}$. As the planting dates delayed, seed cotton yield, number of bolls per plant and seed cotton weight per boll decreased while number of days from sowing to first boll opening, plant height and fiber fineness increased. Sowing dates were not significantly different concerning number of sympodia, seed index, ginning outturn, fiber length, fiber strength and fiber uniformity. Cultivars Stoneville 468, BA 119, DP 499 and PG 2018 had preferable seed cotton yields compared to the other ones.
\end{abstract}

Keywords: cotton, planting time, cultivars, yield, fiber quality

\section{Introduction and literature review}

Among the industrial crops, cotton has the highest planting area and production value and has an important place in Turkish exports. Cotton is a plant that requires more input usage than many agricultural products. Low prices due to inadequate support policies and high production costs in cotton farming have negatively affected cotton cultivation in recent years and cultivation areas have decreased. Cotton was planted in an area of 518000 hectares from which 976000 tons of cotton fiber was produced in 2018 in Turkey (Anonymous, 2019). Turkey had been characterized as an exporter country of cotton in past years. However, depending on the developments in the textile and confection sector, especially after the 1990s, it started to import a significant amount of cotton and today it has become the fifth country with 680000 tons after Bangladesh, China, Indonesia and Pakistan. In other words, the amount of cotton production in our country cannot fully meet the demands of the textile and confection sector and the increasing demand is met through imports. 
Aegean, Mediterranean (Cukurova and Antalya) and Southeastern Anatolia Regions were the main cotton production places in Turkey although $56 \%$ of the cotton produced in Southeastern Anatolia Region, especially $40 \%$ is produced in the province of Sanliurfa (Anonymous, 2019). Therefore Sanliurfa province has an important role in cotton production in Turkey. This ratio is expected to increase with the completion of SAP (Southeastern Anatolian Project) irrigation and energy project.

Producing the amount of fiber cotton needed in Turkey by using our own resources will reduce our dependence on foreign sources and prevent foreign exchange losses for imports. The way to increase cotton production is by expanding plantation areas, using available resources economically or by increasing productivity per unit area. In the fields where wheat-cotton alternation is applied in Turkey, the fields remain empty for about 10 months until the cotton or another main product is sown after the wheat harvest. Especially in areas where irrigation is possible, plants such as corn, soybean and peanut can be sown as second crop. In these areas, spreading the cultivation of early cotton cultivars like a second crop can be an economic cultivation aimed at increasing production since cotton can yield in a shorter period. In Sanliurfa province, first crop was cultivated in approximately 210000 ha area and second crop was cultivated in 20000 ha area (Anonymous, 2019).

All of the cotton varieties cultivated in Turkey belong to Gossypium hirsutum L. species. Cotton production is a form of production depending on environmental conditions. In addition to the ecological differences, the differences in the cotton production techniques applied as well as genetic structure of the varieties grown in cotton production regions can lead to the formation of the yield and quality quite differently from each other (Killi, 2005). Nowadays, the main purpose of cotton production is to improve the technological properties of fiber as well as high yield, to increase earliness, ginning efficiency, resistance to diseases and pests and to reduce production costs.

In recent years, especially in the studies conducted for cotton production after barley and wheat in Turkey, early cultivation of varieties can be done successfully but yield is reduced and fiber technology features are partially adversely affected respect to the main product planting (Killi, 2005; Killi and Bolek, 2006). There is a need to search the effect of different sowing times on yield and fiber technological properties of mid-early cotton cultivars that grow as second crop conditions especially considering lentil, barley and wheat production. In the second crop conditions, it is possible to tolerate the decrease in yields in cotton production by determining the varieties of cotton which are efficient in sowing time, having grater fiber-technological features, earlier, resistant to diseases and pests. As a matter of fact, in the study carried out with the varieties belonging to different mature groups under the second crop conditions, it is stated that cotton production can be made with early or middle early varieties (Copur and Yuka, 2016).

In the Sanliurfa Harran and Viransehir Plains, producers have recently turned to second crop cotton after lentil, barley and wheat. Producers have problems in choosing the cultivar and the date of planting.

This study was carried out in order to determine yield and fiber properties of some cotton cultivars at different sowing times in the second crop conditions of Sanliurfa Harran Plain and to give practical information to the producers about the second crop cotton cultivation and to shed light on the studies to be done on this subject. 


\section{Materials and methods}

Field trials were carried out on a clay textured soil (vertic calciorthid aridisol) during the 2014 and 2015 double crop cotton-growing seasons at Faculty of Agriculture Research and Application Centre of Harran University located in Sanliurfa, Turkey. The experimental site is located in Harran Plain (altitude: $465 \mathrm{~m} ; 37^{\circ} 08^{\prime}$ North and $38^{\circ} 46^{\prime}$ East), near to the Turkish-Syrian border (Figs. 1 and 2). The soil texture was of clay loam-type (Anonymous, 2006). Average field capacity, permanent wilting point, dry bulk density and $\mathrm{pH}$ of the site at $90 \mathrm{~cm}$ soil depth were $32 \%, 22 \%, 1.41 \mathrm{~g} \mathrm{~cm}^{-3}$ and 7.2 , respectively (Table 1).

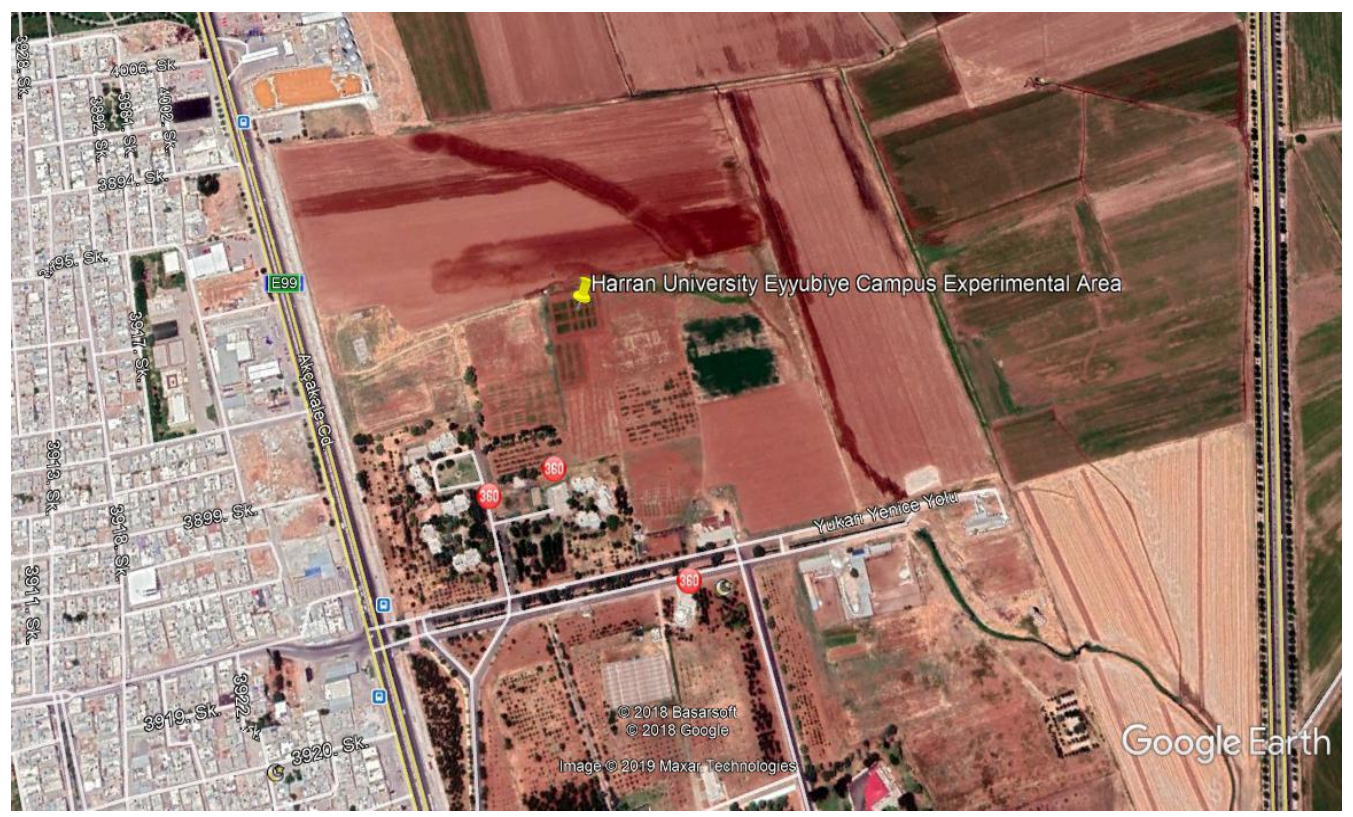

Figure 1. The map of the experimental area

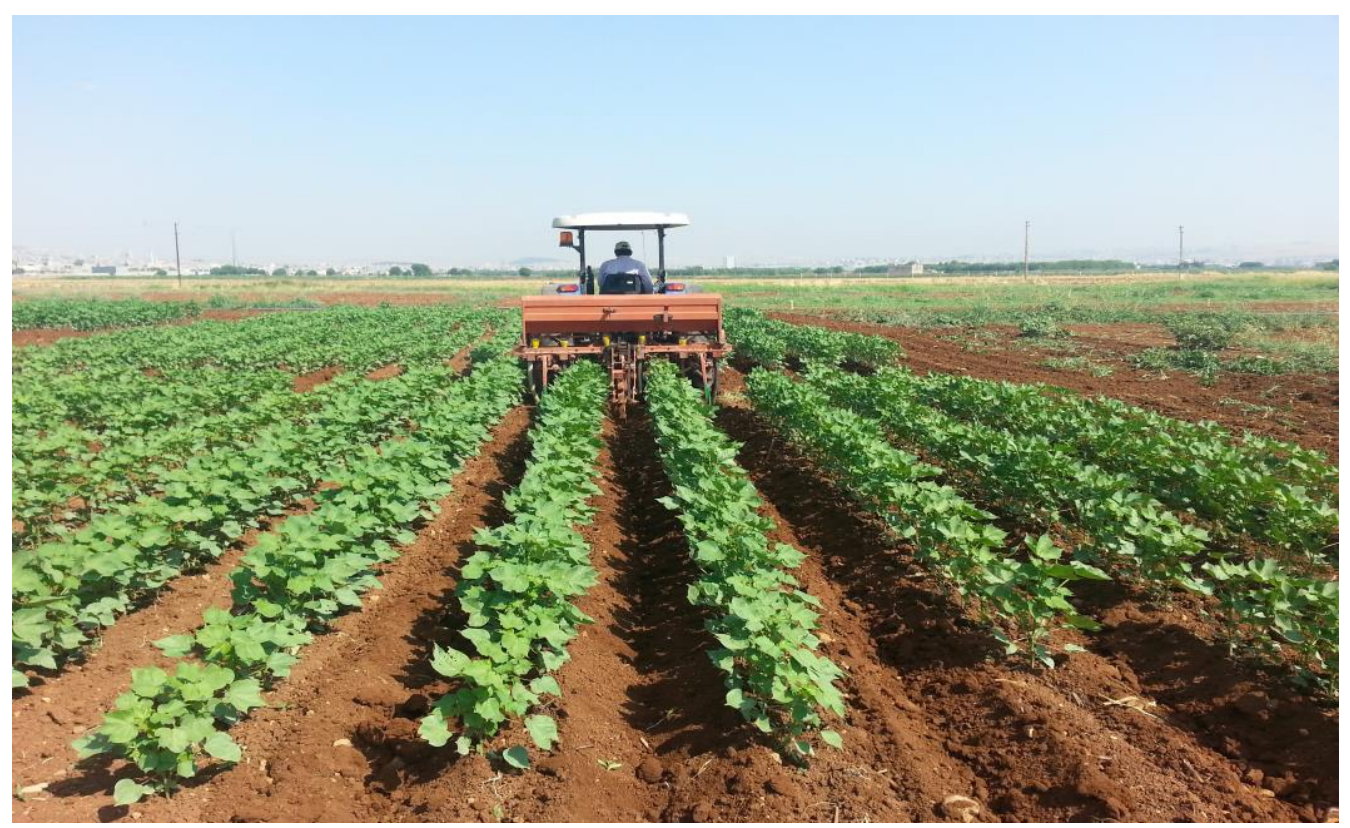

Figure 2. Photography from the experimental field 
Table 1. Some soil properties of the study area (Harran University Research Station, Sanliurfa, Turkey)

\begin{tabular}{|c|c|c|c|c|c|c|c|c|c|c|c|}
\hline \multirow{2}{*}{$\begin{array}{c}\text { Depth } \\
(\mathbf{c m})\end{array}$} & \multirow{2}{*}{$\begin{array}{c}\text { BD } \\
\left(\mathrm{g} \mathrm{cm}^{-3}\right)\end{array}$} & \multirow{2}{*}{$\begin{array}{l}\text { OM } \\
(\%)\end{array}$} & \multicolumn{3}{|c|}{$\begin{array}{l}\text { Soil particle distribution } \\
(\%)\end{array}$} & \multirow[t]{2}{*}{$\mathbf{p H}$} & \multirow{2}{*}{$\begin{array}{c}\mathbf{N} \\
\left(\mathrm{kg} \mathrm{ha}^{-1}\right)\end{array}$} & \multirow{2}{*}{$\begin{array}{c}\mathbf{P}_{2} \mathrm{O}_{5} \\
\left(\mathrm{~kg} \mathrm{~h}^{-1}\right)\end{array}$} & \multirow{2}{*}{$\begin{array}{c}\mathbf{K}_{2} \mathbf{O} \\
\left(\mathbf{k g ~ h a}^{-1}\right)\end{array}$} & \multirow{2}{*}{$\begin{array}{l}\text { FC } \\
(\%)\end{array}$} & \multirow{2}{*}{$\begin{aligned} \text { PWP } \\
(\%)\end{aligned}$} \\
\hline & & & Sand & Silt & Clay & & & & & & \\
\hline $0-30$ & 1.37 & 1.2 & 7 & 3 & 59 & 7.3 & 25 & 27 & 1280 & 31.5 & 22.2 \\
\hline $30-60$ & 1.40 & 0.8 & 17 & 25 & 58 & 7.2 & 12 & 20 & 900 & 31.8 & 22.6 \\
\hline $60-90$ & 1.43 & 0.6 & 20 & 21 & 59 & 7.2 & 6 & 17 & 810 & 32.3 & 21.5 \\
\hline $90-120$ & 1.43 & 0.5 & 19 & 20 & 62 & 7.2 & - & - & - & 32.5 & 21.5 \\
\hline
\end{tabular}

BD: bulk density, OM: organic matter, FC: field capacity, PWP: permanent wilting point

The average air temperatures were in $12{ }^{\circ} \mathrm{C}-32.5{ }^{\circ} \mathrm{C}$ range during the double crop cotton growing season, while relative humidity was below $50 \%$ in June, July and August for the both treatment years (Table 2; Anonymous, 2016). After the wheat had been harvested, the tillage was done in the trial area and the seeds of the cotton were drilled and then the trial area was irrigated by sprinkler system according to sowing times. In the scope of the study, seeds of cotton cultivars were sown according to sowing dates with the randomized complete block with split plot experimental design with three replications. Sowing dates (June $1^{\text {st }}$, June $10^{\text {th }}$ and June $20^{\text {th }}$ ) were kept in main plot and cultivars (Stoneville 468, BA 119, DP 499 and PG 2018) were in sub plot and cultivars are widely cultivated in southeast of Turkey. The plots consisted of four rows, $10 \mathrm{~m}$ in length with inter-row spacing of $70 \mathrm{~cm}$ and intra-row spacing of $15 \mathrm{~cm}$; oriented in south-north direction; and hand-thinned to 6 to 7 plants per meter row when the seedlings had approximately three true leaves. The cotton was sown in each plot at 4-5 $\mathrm{cm}$ depth by an experimental driller on June $1^{\text {st }}$, June $10^{\text {th }}$, and June $20^{\text {th }}, 2014$ and 2015. Pre-plant fertilizer was applied at a rate of $70 \mathrm{~kg} \mathrm{~N} \mathrm{ha}^{-1}$ and $70 \mathrm{~kg} \mathrm{P} \mathrm{ha}^{-1}$ as 20-200 compose fertilizer and followed by $90 \mathrm{~kg} \mathrm{ha}^{-1} \mathrm{~N}$ as $46 \%$ urea applied at the initiation of flowering. $\mathrm{K}_{2} \mathrm{O}$ was not applied due to its abundance in the soil. A total of 900,860 and $800 \mathrm{~mm}$ of water were applied in respect to sowing times from cotton sowing to harvest. The first irrigation was applied 4 weeks after each sowing time and the other irrigation was done 9, 8 and 7 times in 10-day intervals respectively. Last irrigation was done when $10 \%$ of the bolls in the plots opened.

During the cultivation season in the trial years, the plots were hoed twice by hand and three times by tractor hoe. $1500 \mathrm{~g} \mathrm{ha}^{-1}$ fluazifop-p-butyl herbicide was used against narrow-leaved weeds. $1500 \mathrm{ml} \mathrm{ha}^{-1}$ dose of lambda cyhalothrin and $200 \mathrm{ml} \mathrm{ha}^{-1}$ thiamethoxam insecticide were used against the cotton boll worm and aphid pest. No fungicides were used for the diseases.

A 2-m border spacing was left between blocks to reduce edge effects. Also before harvesting, $0.5 \mathrm{~m}$ was left in each plot's top and bottom, and 1 row was left as side effect from each side of every plot. Seed cotton samples were hand harvested from all plants, from 9-m sections of the two middle rows in each four row plot. The first handpicking was done on October $23^{\text {rd }}, 2014$ and October $15^{\text {th }}, 2015$, and the second handpicking was done on November $6^{\text {th }}, 2014$ and November $4^{\text {th }}, 2015$.

Seed cotton yield, number of days from sowing to first boll opening, plant height, number of sympodia, number of bolls per plant, seed cotton weight per boll, ginning outturn and seed index were determined according to Worley et al. (1976). 
Approximately a 300-g seed cotton sample collected from each plot was ginned to determine fiber length, fiber fineness, fiber strength and fiber uniformity. Fiber tests were conducted at a relative humidity of $65 \pm 2 \%$ and a temperature of $20 \pm 1{ }^{\circ} \mathrm{C}$ to determine fiber characters were measured by High Volume Instrument (HVI-1000) test device (Anonymous, 1997). Statistical analysis was performed using the MSTATC statistical program (Anonymous, 1989). Means were separated using Fisher's protected least significant differences (LSD) test and $\mathrm{P}<0.05$ denotes the level of significance.

Table 2. Climatic data of the experimental area during cotton crop growing season for the years 2014 and 2015

\begin{tabular}{|c|c|c|c|c|c|c|}
\hline Climatic parameters & June & July & August & September & October & November \\
\hline \multicolumn{7}{|c|}{2014} \\
\hline Min. air temp. $\left({ }^{\circ} \mathrm{C}\right)$ & 15.3 & 20.3 & 20.2 & 14.5 & 9.5 & 4.8 \\
\hline Max. air temp. $\left({ }^{\circ} \mathrm{C}\right)$ & 40.1 & 43.4 & 43.5 & 40.6 & 31.9 & 22.8 \\
\hline Average air temp. $\left({ }^{\circ} \mathrm{C}\right)$ & 28.4 & 32.5 & 32.4 & 26.2 & 20.3 & 12.1 \\
\hline Relative humidity (\%) & 43.8 & 35.2 & 38.8 & 41.0 & 49.5 & 53.9 \\
\hline Wind speed $\left(\mathrm{ms}^{-1}\right)$ & 1.9 & 1.9 & 1.5 & 1.5 & 1.0 & 1.6 \\
\hline Soil temperature $\left({ }^{\circ} \mathrm{C}\right)$ & 30.4 & 34.4 & 35.6 & 27.8 & 20.6 & 11.3 \\
\hline Rainfall (mm) & 20.6 & ------ & 1.0 & 28.8 & 25.7 & 78.6 \\
\hline \multicolumn{7}{|c|}{2015} \\
\hline Min. air temp. $\left({ }^{\circ} \mathrm{C}\right)$ & 16.7 & 21.4 & 22.1 & 18.7 & 12.7 & 6.8 \\
\hline Max. air temp. $\left({ }^{\circ} \mathrm{C}\right)$ & 38.4 & 42.8 & 43.1 & 40.4 & 33.0 & 24.3 \\
\hline Average air temp. $\left({ }^{\circ} \mathrm{C}\right)$ & 27.7 & 33.2 & 31.5 & 29.8 & 21.6 & 14.0 \\
\hline Relative humidity (\%) & 40.1 & 37.9 & 37.4 & 42.7 & 50.5 & 51.2 \\
\hline Wind speed $\left(\mathrm{ms}^{-1}\right)$ & 1.9 & 1.7 & 1.6 & 1.3 & 1.4 & 1.5 \\
\hline Soil temperature $\left({ }^{\circ} \mathrm{C}\right)$ & 29.0 & 32.3 & 32.9 & 30.7 & 24.6 & 13.8 \\
\hline Rainfall (mm) & 0.7 & 0.2 & --- & --- & 58.8 & 7.9 \\
\hline \multicolumn{7}{|c|}{ Average temperatures for 46 years period $(1970-2016)$} \\
\hline Min. air temp. $\left({ }^{\circ} \mathrm{C}\right)$ & 10.0 & 16.00 & 16.0 & 11.2 & 2.5 & -2.7 \\
\hline Max. air temp. $\left({ }^{\circ} \mathrm{C}\right)$ & 44.0 & 46.8 & 44.8 & 42.0 & 36.4 & 29.4 \\
\hline Average air temp. $\left({ }^{\circ} \mathrm{C}\right)$ & 28.2 & 32.0 & 31.2 & 26.8 & 20.3 & 7.5 \\
\hline Relative humidity (\%) & 34.9 & 32.2 & 35.3 & 37.9 & 47.5 & 69.9 \\
\hline Wind speed $\left(\mathrm{ms}^{-1}\right)$ & 2.4 & 2.4 & 2.2 & 1.9 & 1.4 & 1.4 \\
\hline Soil temperature $\left({ }^{\circ} \mathrm{C}\right)$ & 33.2 & 37.4 & 36.3 & 31.0 & 22.6 & 13.4 \\
\hline Rainfall (mm) & 3.6 & 0.7 & 1.1 & 3.2 & 25.3 & 46.0 \\
\hline
\end{tabular}

\section{Results and discussion}

\section{Seed cotton yield ( $\left.\mathrm{kg} \mathrm{ha}^{-1}\right)$}

The averaged seed cotton yield (SCY) in terms of cultivars changed between $2579.36 \mathrm{~kg} \mathrm{ha}^{-1}$ and $3374.97 \mathrm{~kg} \mathrm{ha}^{-1}$ in both years and the average was $2961.30 \mathrm{~kg} \mathrm{ha}^{-1}$ and $3019.30 \mathrm{~kg} \mathrm{ha}^{-1}$ in 2014 and 2015, respectively (Table 3). The highest averaged SCY was obtained from Stoneville 468 and the lowest SCY was obtained from PG 2018 cultivar (Table 3). In terms of sowing times, SCY varied from $1932.93 \mathrm{~kg} \mathrm{ha}^{-1}$ to $4154.64 \mathrm{~kg} \mathrm{ha}^{-1}$ (Table 3). According to LSD (Least Significant Difference) test, different cotton yield groups were formed in terms of sowing times and cultivars and 
that SCY decreases with delay of sowing time. This may be due to the lack of sufficient photosynthesis and the reduction of dry matter accumulation, since there was not enough temperature for the development of plants with the delay of sowing time. Therefore, plantings at June $10^{\text {th }}$ and $20^{\text {th }}$ requires a longer period of time for the development and opening of the bolls with the cooling during boll opening period (Gormus and Yucel, 2002). Sowing date $\mathrm{x}$ cultivar interaction was statistically significant meaning that SCY was affected by both sowing time and cultivars (Table 3). SCY is the result of interaction of genotypes with the environment. Therefore, the highest SCY was obtained from June $1^{\text {st }}$ sowing in addition to cultivars Stoneville 468 and BA 119. This may be due to the similar adaptability of these cultivars to ecological conditions. These varieties have high adaptability and are medium-early varieties, thus opening earlier bolls and higher seed cotton yield. Therefore, Stoneville 468 and BA 119 varieties can be recommended under second crop conditions. Our findings are in agreement with the findings of Copur (1999), Copur et al. (2001), Dong et al. (2006), Barradas and Bellido (2009), Braunack et al. (2012), Baran (2013), Karademir et al. (2013), Copur and Yuka (2016), Wumbei (2014) and Du et al. (2015).

\section{Number of days from sowing to first boll opening (days)}

The average number of days from sowing to first boll opening (DTB) ranged from 98 days to 116 days; the mean was 107.25 days in 2014 and 108.53 days in 2015. In terms of cultivars, the highest averaged DTB belonged to PG 2018 while Stoneville 458 was the earliest (Table 3). In terms of sowing times, DTB varied between 104.25 and 111.33 days. As a result of the variability analysis there was a significant (0.01) difference between sowing dates and cultivars in both years in terms of DTB (Table 3). According to the LSD test, different groupings formed for DTB that increases with the delay of sowing time. It can be observed that plants open bolls with a delay of approximately 5 days compared to June $1^{\text {st }}$ and June $20^{\text {th }}$. Stoneville 468 and BA 119 varieties are middle early varieties, thus forming bolls earlier than other varieties. As a matter of fact, these varieties also produced higher cotton yields than other varieties. Our findings are consistent with the findings of Copur (1999) that the number of days has increased with the delay of sowing date. It is seen that there is a 4-5 day difference between cultivars in terms of DTB. This difference may be due to the genotype effect, as well as the different response of the varieties to climate and soil conditions. Our findings have similarities of Soyler and Temel (2007), Ozbek et al. (2009), Baran (2013) and Iqbal et al. (2018).

\section{Plant height (cm)}

The plant height $(\mathrm{PH})$ values of the cultivars varied between $96.44 \mathrm{~cm}$ and $120.96 \mathrm{~cm}$ in 2014 and the average was $106.16 \mathrm{~cm}$ while the values ranged from $98.91 \mathrm{~cm}$ to $118.73 \mathrm{~cm}$ and the average was $106.71 \mathrm{~cm}$ in 2015 . In terms of cultivars, the highest PH was obtained from DP-499 and the lowest was obtained from Stoneville 458 variety (Table 3). In terms of sowing times, the averaged PH in 2014 was between $100.8 \mathrm{~cm}$ and $112.78 \mathrm{~cm}$ and between 103.69 and $110.32 \mathrm{~cm}$ in 2015 (Table 3). As a result of the variability analysis, sowing dates, cultivars and sowing date $\mathrm{x}$ cultivar interaction were significantly (0.05 and 0.01) different regarding to $\mathrm{PH}$ (Table 3). According to the LSD test, different $\mathrm{PH}$ groups were formed in terms of sowing dates and that it increases on the $10^{\text {th }}$ of June and with the delay of sowing time it decreased 
on June $20^{\text {th }}$. This is due to the shorter vegetation period in late sowing and the limitation of the growth of plants due to the difference in day and night temperature (Usman et al., 2016). Sowing date $x$ cultivar interaction was also important in both years. The highest plants were obtained from June $10^{\text {th }}$ and DP-499 cultivars and the shortest plants were obtained from June $20^{\text {th }}$ and Stoneville-468 cultivars. Specifically, DP-499 was taller than other varieties and thus plants were more vegetatively developed. The lower yield values of the DP-499 cultivar compared to the Stoneville 468 and BA-119 cultivars support our findings. This may be due to the effects of the growth and development cycles of cotton cultivars on different environmental conditions planted in different sowing dates. Our findings are in line with the findings of Copur (1999), Soyler and Temel (2007), Ozbek et al. (2009), Baran (2013) and Copur and Yuka (2016) that plant height increases with delay of sowing date.

Table 3. Seed cotton yield, number of days from sowing to first boll opening, plant height and their contributions in response to different sowing date and cultivars in 2014 and 2015

\begin{tabular}{|c|c|c|c|c|c|c|}
\hline \multirow[t]{2}{*}{ Sowing date (SD) } & \multicolumn{2}{|c|}{$\begin{array}{l}\text { Seed cotton yield } \\
\quad\left(\mathrm{kg} \mathrm{ha}^{-1}\right)\end{array}$} & \multicolumn{2}{|c|}{$\begin{array}{l}\text { Number of days from } \\
\text { sowing to first boll } \\
\text { opening (days) }\end{array}$} & \multicolumn{2}{|c|}{ Plant height (cm) } \\
\hline & 2014 & 2015 & 2014 & 2015 & 2014 & 2015 \\
\hline $1-1^{\text {th }}$ June & $4154.64 \mathrm{a}$ & $4118.53 \mathrm{a}$ & $104.25 \mathrm{~b}$ & $105.58 \mathrm{c}$ & $100.08 \mathrm{c}$ & $103.69 \mathrm{~b}$ \\
\hline $2-10^{\text {th }}$ June & $2796.33 \mathrm{~b}$ & $2886.80 \mathrm{~b}$ & $108.25 \mathrm{a}$ & $108.67 \mathrm{~b}$ & $112.78 \mathrm{a}$ & $110.32 \mathrm{a}$ \\
\hline $3-20^{\text {th }}$ June & $1932.93 \mathrm{c}$ & $2052.58 \mathrm{c}$ & $109.25 \mathrm{a}$ & $111.33 \mathrm{a}$ & $105.62 \mathrm{~b}$ & $106.11 \mathrm{~b}$ \\
\hline \multicolumn{7}{|l|}{ Cultivars } \\
\hline 1-Stoneville 468 & $3374.97 \mathrm{a}^{*}$ & $3314.74 \mathrm{a}$ & $101.67 \mathrm{~d}^{*}$ & $98.00 \mathrm{~d}$ & $96.44 \mathrm{c}^{*}$ & $98.91 \mathrm{c}$ \\
\hline 2-BA 119 & $3222.58 \mathrm{a}$ & $3276.73 \mathrm{a}$ & $105.00 \mathrm{c}$ & $107.78 \mathrm{c}$ & $99.54 \mathrm{c}$ & $100.16 \mathrm{c}$ \\
\hline 3-DP 499 & $2668.28 \mathrm{~b}$ & $2795.84 \mathrm{~b}$ & $109.00 \mathrm{~b}$ & $111.78 \mathrm{~b}$ & $120.96 \mathrm{a}$ & $118.78 \mathrm{a}$ \\
\hline 4- PG 2018 & $2579.36 \mathrm{~b}$ & $2689.90 \mathrm{~b}$ & $113.33 \mathrm{a}$ & $116.56 \mathrm{a}$ & $107.69 \mathrm{~b}$ & $109.02 \mathrm{c}$ \\
\hline \multicolumn{7}{|l|}{ Interaction } \\
\hline SD1xC1 & $4560.53 \mathrm{a}$ & 4483.47 & 98.00 & 94.00 & $83.53 \mathrm{~g}$ & $93.33 \mathrm{~d}$ \\
\hline $\mathrm{SD} 1 \mathrm{xC} 2$ & $4520.30 \mathrm{a}$ & 4420.00 & 102.00 & 104.67 & $93.30 \mathrm{f}$ & $97.10 \mathrm{~cd}$ \\
\hline SD1xC3 & $3973.83 \mathrm{~b}$ & 3903.55 & 107.00 & 110.33 & $115.17 \mathrm{bc}$ & $116.93 \mathrm{ab}$ \\
\hline SD1xC4 & $3563.90 \mathrm{c}$ & 3667.11 & 110.00 & 113.33 & $108.33 \mathrm{~cd}$ & $107.40 \mathrm{bc}$ \\
\hline $\mathrm{SD} 2 \mathrm{xC} 1$ & $2957.31 \mathrm{~d}$ & 3016.84 & 103.00 & 97.67 & $103.60 \mathrm{de}$ & $100.73 \mathrm{~cd}$ \\
\hline $\mathrm{SD} 2 \mathrm{xC} 2$ & $2963.74 \mathrm{~d}$ & 3110.20 & 107.00 & 109.67 & $105.33 \mathrm{de}$ & $102.30 \mathrm{~cd}$ \\
\hline $\mathrm{SD} 2 \mathrm{xC} 3$ & $2530.49 \mathrm{e}$ & 2753.45 & 110.00 & 111.67 & $127.57 \mathrm{a}$ & $117.30 \mathrm{ab}$ \\
\hline $\mathrm{SD} 2 \mathrm{xC} 4$ & $2733.75 \mathrm{de}$ & 2666.71 & 113.00 & 115.67 & $114.60 \mathrm{bc}$ & $120.93 \mathrm{a}$ \\
\hline $\mathrm{SD} 3 \mathrm{xC} 1$ & $2607.07 \mathrm{e}$ & 2443.91 & 104.00 & 102.33 & $102.20 \mathrm{de}$ & $102.67 \mathrm{~cd}$ \\
\hline $\mathrm{SD} 3 \mathrm{xC} 2$ & $2183.72 \mathrm{f}$ & 2300.00 & 106.00 & 109.00 & $100.00 \mathrm{ef}$ & $101.08 \mathrm{~cd}$ \\
\hline $\mathrm{SD} 3 \mathrm{xC} 3$ & $1500.50 \mathrm{~g}$ & 1730.51 & 110.00 & 113.33 & $120.13 a b$ & $121.97 \mathrm{a}$ \\
\hline $\mathrm{SD} 3 \mathrm{xC} 4$ & $1440.43 \mathrm{~g}$ & 1735.89 & 117.00 & 120.67 & 100.13 ef & $98.73 \mathrm{~cd}$ \\
\hline Grand mean & 2961.30 & 3019.30 & 107.25 & 108.53 & 106.16 & 106.71 \\
\hline LSD (SD) & 85.21 & 137.40 & 1.60 & 1.00 & 3.98 & 3.31 \\
\hline $\operatorname{LSD}(\mathrm{C})$ & 196.00 & 157.30 & 3.09 & 1.93 & 4.39 & 6.47 \\
\hline SDxC interaction & 339.50 & $\mathrm{~ns}$ & $\mathrm{~ns}$ & $\mathrm{~ns}$ & 7.60 & 11.21 \\
\hline C.V. \% & 6.68 & 5.26 & 1.97 & 1.79 & 4.17 & 6.12 \\
\hline
\end{tabular}

*Means in each column followed by the same letter are not significantly different $(\mathrm{p}<0.05)$. SD: sowing date, $\mathrm{C}$ : cultivar 


\section{Number of bolls per plant (no. plant ${ }^{-1}$ )}

The number of bolls per plant (BPP) is one of the most important characteristics affecting the cotton yield. The genotypic structure and cultivation techniques of the varieties may affect the number of bolls (Usman et al., 2016). With increasing BBP, cotton yield increases. Variance analysis showed that the BBP was affected by different sowing dates and different cultivars in both years. Although different BBP groups were formed, but the sowing date $\mathrm{x}$ cultivar interaction was not significant (Table 4). BPP decreased with the delay of sowing time. On the other hand, the BPP obtained in June $1^{\text {st }}$ sowing has led to $40 \%$ more bolls compared to June $20^{\text {th }}$ sowing. Decreasing BPP because of late sowing is due to short vegetation time led to decrease number of flowers formed on the plant and insufficient carbohydrate production effecting flowers not to develop into bolls thus shed off the plant. As a matter of fact, the decrease in cotton yield with delayed sowing supports our findings. The average BPP was between 7.96 plant $^{-1}$ and 11.89 plant $^{-1}$ in 2014, with an average of 9.98 plant $^{-1}$ and similar results occurred in 2015. In terms of cultivars, the highest BPP was obtained from Stoneville 468 and the lowest BPP was obtained from PG 2018 (Table 4). There were also differences in terms of BPP among the cultivars and that the cultivars yielding the least seed cotton constitute the least BPP (Table 4). This may be due to the different reactions of the cultivars to different genotypic structure and environmental conditions. Stoneville 468 variety constitutes the highest number of bolls, thus producing the highest seed cotton yield. Copur (1999), Arshad et al. (2007), Soyler and Temel (2007), Ali et al. (2009), Ozbek et al. (2009), Baran (2013), Copur and Yuka (2016) and Usman et al. (2016) reported that the number of bolls decreased with delay in planting and there were significant differences between cotton varieties.

\section{Number of sympodia (no. plant ${ }^{-1}$ )}

The number of sympodia (SYM) affects the number of bolls per plant and hence the cotton yield. Number of fruit branches was affected by different sowing dates and varieties according to statistical analysis, but sowing date $\mathrm{x}$ cultivar interaction was insignificant in 2014 and significant in 2015 (Table 4). Thus SYM decreased with the delay of sowing time. Similar findings were found by Copur (1999), Gur et al. (2001) and Soyler and Durmus (2007) and Baran (2013). The average SYM of cotton cultivars ranged from 11.58 to 13.80 number plant $^{-1}$ averaging 12.57 number plant $^{-1}$ in 2014 while it was between 9.62 and 11.93 number plant ${ }^{-1}$ averaging 11.05 number plant $^{-1}$ in 2015. DP 499 and Stoneville 458 had the highest SYM in 2014 and 2015, respectively while PG-2018 had the lowest SYM in both years (Table 4). Different groups were formed in terms of SYM in cotton cultivars. Although the cotton cultivars used in the experiment are in the same maturation group, they can form different SYM due to differences in genotype structure in adaptation to different environmental conditions (Copur, 2006; Soyler and Temel, 2007; Ozbek et al., 2009; Baran, 2013; Copur and Yuka, 2016 and Iqbal et al., 2018).

\section{Seed cotton weight per boll ( $\mathrm{g}$ boll $\left.^{-1}\right)$}

Seed cotton weight (SCW) was significantly influenced by different sowing dates and cultivars. According to the LSD test, different SCW groups were formed in terms of sowing dates and the SCW decreases with delay of sowing time. The highest SCW was obtained from June $1^{\text {st }}$ sowing and DP 499 cultivars while the lowest SCW was 
obtained from June $20^{\text {th }}$ and BA 119 cultivars in both years. The average SCW was $4.75 \mathrm{~g}$ in 2014 and $4.67 \mathrm{~g}$ in 2015. The decrease in SCW compared to sowing date shows that plants cannot produce enough carbohydrates for boll development due to low night temperature during the boll development period (Copur, 1999; Ali et al., 2009; Usman et al., 2016 and Iqbal et al., 2018). Therefore, a higher yield of cotton was obtained in June $1^{\text {st }}$ sowing. In addition, there were differences in terms of SCW (Table 4). The highest SCW was obtained from DPL 499 variety but it did not produce the highest yield of cotton per hectare. This may be due to the fact that the number of bolls in the mentioned variety was low compared to other productive cultivars and the resulting carbohydrates were used in a less number of bolls (Pettigrew, 2002; Dong et al., 2006; Baran, 2013 and Copur and Yuka, 2016). For this purpose, DPL 499 variety can be selected as a parent in breeding studies that will be carried out for the seed cotton weight.

Table 4. Number of bolls, number of sympodia, seed cotton weight and their contributions in response to different sowing date and cultivars in 2014 and 2015

\begin{tabular}{|c|c|c|c|c|c|c|}
\hline \multirow[t]{2}{*}{ Sowing date (SD) } & \multicolumn{2}{|c|}{$\begin{array}{c}\text { Number of bolls } \\
\left(\text { no. plant }{ }^{-1}\right)\end{array}$} & \multicolumn{2}{|c|}{$\begin{array}{c}\text { Number of sympodia } \\
\left(\text { no. } \text { plant }^{-1}\right)\end{array}$} & \multicolumn{2}{|c|}{$\begin{array}{c}\text { Seed cotton weight } \\
\left(\mathrm{g} \mathrm{boll}^{-1}\right)\end{array}$} \\
\hline & 2014 & 2015 & 2014 & 2015 & 2014 & 2015 \\
\hline $1-1^{\text {th }}$ June & $11.88 \mathrm{a}$ & $11.72 \mathrm{a}$ & 13.52 & $11.93 \mathrm{a}$ & $4.96 \mathrm{a}$ & $4.97 \mathrm{a}$ \\
\hline $2-10^{\text {th }}$ June & $10.13 \mathrm{~b}$ & $9.59 \mathrm{~b}$ & 12.63 & $11.61 \mathrm{a}$ & $4.79 \mathrm{a}$ & $4.87 \mathrm{~b}$ \\
\hline $3-20^{\text {th }}$ June & $7.92 \mathrm{c}$ & $7.59 \mathrm{c}$ & 11.52 & $9.62 \mathrm{~b}$ & $4.50 \mathrm{~b}$ & $4.20 \mathrm{c}$ \\
\hline \multicolumn{7}{|l|}{ Cultivars (C) } \\
\hline 1-Stoneville 468 & $11.89 \mathrm{a}^{*}$ & $11.33 \mathrm{a}$ & $12.89 \mathrm{ab}^{*}$ & $11.99 \mathrm{a}$ & $4.66 b^{*}$ & $4.62 \mathrm{c}$ \\
\hline 2-BA 119 & $11.11 \mathrm{a}$ & $9.74 \mathrm{~b}$ & $11.96 \mathrm{bc}$ & $11.07 \mathrm{a}$ & $4.65 \mathrm{~b}$ & $4.53 \mathrm{c}$ \\
\hline 3-DP 499 & $8.94 \mathrm{~b}$ & $9.12 \mathrm{bc}$ & $13.80 \mathrm{a}$ & $11.10 \mathrm{a}$ & $5.22 \mathrm{a}$ & $5.00 \mathrm{a}$ \\
\hline 4- PG 2018 & $7.96 \mathrm{c}$ & $8.33 \mathrm{c}$ & $11.58 \mathrm{c}$ & $10.04 \mathrm{~b}$ & $4.47 \mathrm{~b}$ & $4.71 \mathrm{~b}$ \\
\hline \multicolumn{7}{|l|}{ Interaction } \\
\hline SD1xC1 & 14.37 & 14.13 & 13.20 & $11.47 \mathrm{bc}$ & 4.76 & $4.62 \mathrm{c}$ \\
\hline $\mathrm{SD} 1 \times \mathrm{xC} 2$ & 12.43 & 11.33 & 12.67 & $11.50 \mathrm{abc}$ & 4.92 & $4.71 \mathrm{c}$ \\
\hline SD1xC3 & 11.10 & 11.13 & 15.03 & $12.00 \mathrm{ab}$ & 5.28 & $5.72 \mathrm{a}$ \\
\hline SD $1 \times C 4$ & 9.63 & 10.27 & 13.17 & $12.73 \mathrm{ab}$ & 4.87 & $4.82 \mathrm{bc}$ \\
\hline $\mathrm{SD} 2 \mathrm{xC} 1$ & 11.57 & 11.37 & 13.10 & $13.20 \mathrm{a}$ & 4.71 & $4.68 \mathrm{c}$ \\
\hline $\mathrm{SD} 2 \mathrm{xC} 2$ & 12.50 & 10.00 & 11.77 & $12.23 \mathrm{ab}$ & 4.57 & $4.67 \mathrm{c}$ \\
\hline $\mathrm{SD} 2 \mathrm{xC} 3$ & 8.07 & 8.33 & 13.70 & $11.47 \mathrm{bc}$ & 5.41 & $5.06 \mathrm{~b}$ \\
\hline $\mathrm{SD} 2 \mathrm{xC} 4$ & 8.37 & 8.67 & 11.97 & $9.53 \mathrm{de}$ & 4.48 & $5.08 \mathrm{~b}$ \\
\hline SD3xC1 & 9.73 & 8.50 & 12.37 & $11.30 \mathrm{bc}$ & 4.51 & $4.09 \mathrm{~d}$ \\
\hline $\mathrm{SD} 3 \mathrm{xC} 2$ & 8.40 & 7.90 & 11.43 & $9.47 \mathrm{de}$ & 4.56 & $4.22 \mathrm{~d}$ \\
\hline $\mathrm{SD} 3 \mathrm{xC} 3$ & 7.67 & 7.90 & 12.67 & $9.83 \mathrm{~cd}$ & 4.97 & $4.23 \mathrm{~d}$ \\
\hline $\mathrm{SD} 3 \mathrm{xC} 4$ & 5.87 & 6.07 & 9.60 & $7.87 \mathrm{e}$ & 4.06 & $4.24 \mathrm{~d}$ \\
\hline Grand mean & 9.98 & 9.63 & 12.57 & 11.05 & 4.75 & 4.67 \\
\hline LSD (SD) & 0.75 & 1.07 & ns & 1.43 & 0.18 & 0.04 \\
\hline $\operatorname{LSD}(\mathrm{C})$ & 0.97 & 0.94 & 0.96 & 0.99 & 0.26 & 0.17 \\
\hline SDxC interaction & ns & ns & ns & 1.72 & ns & 0.29 \\
\hline C.V. \% & 9.81 & 9.89 & 7.73 & 9.07 & 5.59 & 3.64 \\
\hline
\end{tabular}

* Means in each column followed by the same letter are not significantly different $(\mathrm{p}<0.05)$. SD: sowing date, $\mathrm{C}$ : cultivar 


\section{Seed index (g)}

One of the characteristics affecting the cotton yield is seed index. Seed index (SI) was not affected by sowing time in 2014 , but there were significant differences between cultivars, and in 2015, both sowing date and cultivars were significantly different (Table 5). The sowing date x cultivar interaction was significant in 2014 and insignificant in 2015. The highest SI was obtained from a June $1^{\text {st }}$ planting and SI decreased in both years with the delay of sowing time (Table 5). In terms of cultivars, the highest SI was obtained from DP 499 and the lowest was obtained from PG 2018 variety in both years. Since the number of bolls was low in DP 499, all of the carbohydrates were used in a few bolls. Therefore, the seed weight of DP 499 variety was higher than other varieties. Also, the differences between the cultivars may be due to the genotypic structure as well as the adaptability of the cultivars to environmental conditions. Our findings were parallel with the reports of Arshad et al. (2007), Ali et al. (2009), Barradas and Bellido (2009), Baran (2013) and Copur and Yuka (2016), and are partially consistent with the findings of Copur (1999). This may be due to the fact that the trials were conducted in different years and places and the cultivars used in the trials were different.

\section{Ginning outturn (\%)}

Ginning outturn (GO) was not affected by different sowing times in both years, but there were significant (0.01) differences between cultivars and sowing date $\mathrm{x}$ cultivar interaction was not significant (Table 5). In terms of cultivars, the highest GO was determined in PG 2018 and the lowest GO was determined in Stoneville 468 (Table 5). Average GO was $41.05 \%$ in 2014 and $41.58 \%$ in 2015. According to LSD test, different GO groups were formed in terms of cultivars and GO partially decreased with delay of sowing time but it was not statistically significant. The partial reduction in GO with the delay of planting is may be due to weak boll development and consequently the fibres in the seeds did not grow well. In addition, there were differences between the cultivars in terms of GO. PG 2018 variety produced higher gin turnout value compared to other varieties. This may be due to the fact that the cultivars have different genotypic structure in terms of GO. Similar findings are found in Copur (1999), Pettigrew (2002), Arshad et al. (2007), Ali et al. (2009) and Copur and Yuka (2016), Usman et al. (2016), and partially contradicts the findings of Barradas and Bellido (2009) and Baran (2013). This may be due to the fact that the experiments were carried out under different ecological conditions and that the cultivars used in the trials were different.

\section{Fiber length (mm)}

Although fiber length (FL) is an inherited property, it may partially be affected by environmental conditions (Bradow and Davidonis, 2000). FL was not affected by different sowing dates and different cotton cultivars, but the sowing date $\mathrm{x}$ cultivar interactions were insignificant in 2014 and statistically significant in 2015 (Table 5). In 2015, fiber length was affected by variety and environmental interaction. According to the sowing dates and cultivars, the average FL was between $28-29 \mathrm{~mm}$ in both years. When the FL values were examined, all of the cultivars are in the medium-length fiber group (Anonymous, 1997) and all of the fiber values obtained can be used in the textile industry. Bauer et al. (2000), Gormus and Yucel (2002), 
Dong et al. (2006), Killi and Bolek (2006), Ali et al. (2009), Barrdas and Bellido (2009), Saeed et al. (2014) and Saleem et al. (2014) stated that FL was not affected by sowing time, while Copur et al. (2001) stated that FL increases with delay of sowing. This may be due to differences in environmental conditions and genotypic differences.

Table 5. Seed index, ginning outturn, fiber length and their contributions in response to different sowing date and cultivars in 2014 and 2015

\begin{tabular}{|c|c|c|c|c|c|c|}
\hline \multirow{2}{*}{ Sowing date (SD) } & \multicolumn{2}{|c|}{ Seed index $(g)$} & \multicolumn{2}{|c|}{ Ginning outturn (g) } & \multicolumn{2}{|c|}{ Fiber length (mm) } \\
\hline & 2014 & 2015 & 2014 & 2015 & 2014 & 2015 \\
\hline $1-1^{\text {th }}$ June & 9.33 & $9.95 \mathrm{a}$ & 41.41 & 41.58 & 28.50 & 28.57 \\
\hline $2-10^{\text {th }}$ June & 9.32 & $9.00 \mathrm{~b}$ & 41.00 & 41.28 & 30.22 & 28.56 \\
\hline 3- $20^{\text {th }}$ June & 9.12 & $8.42 \mathrm{~b}$ & 40.74 & 42.12 & 29.59 & 29.38 \\
\hline \multicolumn{7}{|l|}{ Cultivars (C) } \\
\hline 1-Stoneville 468 & $9.49 \mathrm{~b}^{*}$ & $9.07 \mathrm{~b}$ & $40.59 b^{*}$ & $41.07 \mathrm{~b}$ & 29.51 & 29.22 \\
\hline 2-BA 119 & $9.09 \mathrm{c}$ & $9.00 \mathrm{~b}$ & $40.79 \mathrm{~b}$ & $40.91 \mathrm{~b}$ & 29.58 & 29.57 \\
\hline 3-DP 499 & $10.01 \mathrm{a}$ & $9.66 \mathrm{a}$ & $40.89 \mathrm{~b}$ & $41.49 \mathrm{~b}$ & 28.96 & 28.14 \\
\hline 4- PG 2018 & $8.43 \mathrm{~d}$ & $8.77 \mathrm{~b}$ & $41.93 \mathrm{a}$ & $42.87 \mathrm{a}$ & 29.69 & 28.42 \\
\hline \multicolumn{7}{|l|}{ Interaction } \\
\hline $\mathrm{SD} 1 \mathrm{xC} 1$ & $9.45 \mathrm{~cd}$ & 10.04 & 41.40 & 40.93 & 28.15 & $28.68 \mathrm{abcd}$ \\
\hline $\mathrm{SD} 1 \times \mathrm{x} 2$ & $9.40 \mathrm{~cd}$ & 9.91 & 41.11 & 41.13 & 28.50 & $29.68 \mathrm{a}$ \\
\hline $\mathrm{SD} 1 \times \mathrm{xC} 3$ & $9.89 \mathrm{abc}$ & 10.47 & 40.86 & 40.42 & 28.04 & 28.12 bcde \\
\hline SD1xC4 & $8.57 \mathrm{e}$ & 9.38 & 42.29 & 43.88 & 29.30 & $27.81 \mathrm{de}$ \\
\hline $\mathrm{SD} 2 \mathrm{xC} 1$ & $9.66 \mathrm{bcd}$ & 8.75 & 40.61 & 41.48 & 30.30 & $29.15 \mathrm{ab}$ \\
\hline $\mathrm{SD} 2 \mathrm{xC} 2$ & $9.52 \mathrm{bcd}$ & 8.72 & 40.78 & 41.34 & 30.03 & $29.07 \mathrm{abc}$ \\
\hline $\mathrm{SD} 2 \mathrm{xC} 3$ & $9.99 \mathrm{ab}$ & 9.69 & 40.64 & 41.89 & 30.58 & 27.95 cde \\
\hline $\mathrm{SD} 2 \mathrm{xC} 4$ & $8.13 \mathrm{e}$ & 8.81 & 41.98 & 42.27 & 29.95 & 28.06 bcde \\
\hline SD3xC1 & $9.37 \mathrm{~d}$ & 8.41 & 39.77 & 40.82 & 30.08 & 28.81abcd \\
\hline SD3xC2 & $8.36 \mathrm{e}$ & 8.36 & 40.50 & 40.24 & 30.23 & $28.97 \mathrm{abc}$ \\
\hline $\mathrm{SD} 3 \mathrm{xC} 3$ & $10.16 \mathrm{a}$ & 8.81 & 41.17 & 42.16 & 28.26 & $27.35 \mathrm{e}$ \\
\hline SD3xC4 & $8.59 \mathrm{e}$ & 8.12 & 41.51 & 42.47 & 29.80 & 28.37 bcde \\
\hline Grand mean & 9.26 & 9.12 & 41.05 & 41.58 & 29.44 & 28.50 \\
\hline LSD (SD) & $\mathrm{ns}$ & 0.65 & $\mathrm{~ns}$ & $\mathrm{~ns}$ & ns & $\mathrm{ns}$ \\
\hline $\operatorname{LSD}(\mathrm{C})$ & 0.29 & 0.43 & 0.76 & 0.87 & ns & ns \\
\hline SDxC interaction & 0.50 & $\mathrm{~ns}$ & ns & $\mathrm{ns}$ & $\mathrm{ns}$ & 1.15 \\
\hline C.V. $\%$ & 3.13 & 4.79 & 1.86 & 2.11 & 3.83 & 2.36 \\
\hline
\end{tabular}

*Means in each column followed by the same letter are not significantly different $(\mathrm{p}<0.05)$. SD: sowing date, C: cultivar

\section{Fiber fineness (micronaire)}

There were statistically significant (0.05) differences at sowing date and cultivars in terms of fiber fineness (FF) in 2014 and 2015 but the sowing date x cultivar interaction were not significant (Table 6). According to LSD test, different FF groups were determined in terms of sowing date and cultivars. According to the same table, the average FF obtained for cultivars was 3.83-4.80 micronaire (mic) in 2014 and the average was $4.21 \mathrm{mic}$ and changed between $3.45-4.43 \mathrm{mic}$ in 2015 the average was 
3.94 mic. The coarser fibres were obtained from DP 499 variety in both years and the finest fibres were obtained from PG 2018 and BA-119 cultivars in 2014 and 2015, respectively. In terms of sowing dates, the average FF in 2014 varied between 3.99$4.52 \mathrm{mic}$ and the average was $4.21 \mathrm{mic}$, in 2015 , it was $3.45-4.43 \mathrm{mic}$ and the average was 3.94 mic (Table 6). The FF value increased by $20 \%$ from June $1^{\text {st }}$ to June 20 . It can be seen that FF increases with delay of sowing time. FF is an inherited property, but it is influenced by many factors (Jost and Cothren, 2000). In particular, temperature and the consequent accumulation of carbohydrates associated with photosynthesis can affect FF. Moreover, the FF (3.99-4.52 mic) values that occurred with sowing time were positively affected due to temperature change (Table 6 ). In addition, there were differences in FF between cultivars. This is due to the fact that the cultivars have different genotypic structure. In the obtained values, except DP 499 variety, other cultivars are in the middle and fine fiber group (Anonymous, 1997). Fibres are thin with delay of sowing (Dong et al., 2006; Ali et al., 2009, Braunack et al., 2012 and Baran, 2013) but Gormus and Yucel (2002), Pettigrew (2002), Barradas and Bellido (2009) and Saleem et al. (2014) reported that fiber fineness is not affected by different sowing times. This may have been due to the different locations and years of the trials and the diversity of the cultivars used.

\section{Fiber strength (g tex $\left.{ }^{-1}\right)$}

Fiber strength (FS) was not significantly affected by sowing date in 2014 but it was significant in 2015 (Table 6). With the delay of sowing, FS was partially increased in 2014 but it was not statistically significant while FS was decreased in 2015 but it was not stable. This may be due to the differences in temperature during the day and night and the change in temperature towards the end of the vegetation period (Bradow and Davidonis, 2000; Killi and Bolek, 2006; Braunack et al., 2012). Significant differences between cultivars occurred in both years; sowing date $\mathrm{x}$ cultivar interaction was insignificant in 2014 but significant in 2015 (Table 6). The average FS was $37.19 \mathrm{~g} \mathrm{tex}^{-1}$ in 2014 and $36.12 \mathrm{~g}$ tex $^{-1}$ in 2015. In terms of cultivars, the highest FS was obtained from DP 499 and the lowest one was obtained from PG 2018 variety. This may be due to the fact that the cultivars have different genotypic structure in terms of fiber strength (Copur and Yuka, 2016; Usman et al., 2016).

\section{Fiber uniformity}

Fiber uniformity (FU) ratio was not affected by different sowing dates and different cotton cultivars and sowing date $\mathrm{x}$ cultivar were found to be insignificant in both years (Table 6). It can be seen from the same table that the FU ratio was $86.35 \%$ in 2014 and $86.25 \%$ in 2016 . In addition, all cultivars $(85-87 \%)$ were ranked as high or good when FU values were examined (Anonymous, 1997). All of the fiber values obtained can be evaluated in the textile industry. Our results indicate that FU rate is not affected by sowing time, whereas it is similar to the findings of Killi and Bolek (2006), Barradas and Bellido (2009) and Saleem et al. (2014) while Usman et al. (2016) reported that FU is affected by different sowing dates and there were differences between the cultivars used in the experiment. This may be due to the fact that the cultivars used in the experiments have different genotypic structure, the application of different cultural processes and different climatic conditions. 
Table 6. Fiber fineness, fiber strength, fiber uniformity and their contributions in response to different sowing date and cultivars in 2014 and 2015

\begin{tabular}{|c|c|c|c|c|c|c|}
\hline \multirow{2}{*}{ Sowing date (SD) } & \multicolumn{2}{|c|}{ Fiber fineness (mic) } & \multicolumn{2}{|c|}{ Fiber strength (g/tex) } & \multicolumn{2}{|c|}{ Fiber uniformity $(\%)$} \\
\hline & 2014 & 2015 & 2014 & 2015 & 2014 & 2015 \\
\hline 1- $1^{\text {th }}$ June & $4.52 \mathrm{a}$ & $4.43 \mathrm{a}$ & 36.48 & $37.25 \mathrm{a}$ & 85.59 & 86.20 \\
\hline $2-10^{\text {th }}$ June & $4.11 \mathrm{~b}$ & $3.95 \mathrm{~b}$ & 37.27 & $34.88 \mathrm{~b}$ & 86.63 & 86.40 \\
\hline $3-20^{\text {th }}$ June & $3.99 \mathrm{~b}$ & $3.45 \mathrm{c}$ & 37.83 & $36.22 \mathrm{ab}$ & 86.83 & 86.14 \\
\hline \multicolumn{7}{|l|}{ Cultivars (C) } \\
\hline 1-Stoneville 468 & $4.24 \mathrm{~b}^{*}$ & $3.81 \mathrm{~b}$ & $36.98 b^{*}$ & $36.48 \mathrm{ab}$ & 86.10 & 86.34 \\
\hline 2-BA 119 & $3.96 \mathrm{bc}$ & $3.52 \mathrm{c}$ & $36.44 \mathrm{~b}$ & $35.69 \mathrm{bc}$ & 86.91 & 86.18 \\
\hline 3-DP 499 & $4.80 \mathrm{a}$ & $4.28 \mathrm{a}$ & $39.16 \mathrm{a}$ & $37.80 \mathrm{a}$ & 86.44 & 86.48 \\
\hline 4- PG 2018 & $3.83 \mathrm{c}$ & $4.17 \mathrm{a}$ & $36.19 \mathrm{~b}$ & $34.57 \mathrm{c}$ & 85.94 & 85.99 \\
\hline \multicolumn{7}{|l|}{ Interaction } \\
\hline SD1xC1 & 4.58 & 4.25 & 36.67 & $36.53 \mathrm{bc}$ & 85.47 & 86.37 \\
\hline $\mathrm{SD} 1 \mathrm{xC} 2$ & 4.30 & 3.69 & 35.53 & $36.57 \mathrm{bc}$ & 85.87 & 86.17 \\
\hline SD1xC3 & 4.96 & 4.88 & 38.50 & $41.47 \mathrm{a}$ & 85.33 & 86.93 \\
\hline $\mathrm{SD} 1 \mathrm{xC} 4$ & 4.23 & 4.92 & 35.23 & $34.43 \mathrm{c}$ & 85.70 & 85.33 \\
\hline $\mathrm{SD} 2 \mathrm{xC} 1$ & 4.01 & 3.85 & 37.63 & $36.53 \mathrm{bc}$ & 86.10 & 86.20 \\
\hline $\mathrm{SD} 2 \mathrm{xC2}$ & 4.16 & 3.78 & 36.27 & $34.63 \mathrm{c}$ & 88.00 & 86.87 \\
\hline $\mathrm{SD} 2 \mathrm{xC} 3$ & 4.67 & 4.16 & 40.30 & $33.87 \mathrm{c}$ & 86.37 & 86.30 \\
\hline $\mathrm{SD} 2 \mathrm{xC} 4$ & 3.61 & 4.03 & 34.87 & $34.50 \mathrm{c}$ & 86.07 & 86.23 \\
\hline $\mathrm{SD} 3 \mathrm{xC} 1$ & 4.13 & 3.32 & 36.63 & $36.37 \mathrm{bc}$ & 86.73 & 86.47 \\
\hline $\mathrm{SD} 3 \mathrm{xC} 2$ & 3.41 & 3.11 & 37.53 & $35.67 \mathrm{bc}$ & 86.87 & 85.50 \\
\hline SD3xC3 & 4.77 & 3.80 & 38.67 & $38.07 \mathrm{~b}$ & 87.63 & 86.20 \\
\hline SD3xC4 & 3.65 & 3.55 & 38.47 & $34.77 \mathrm{c}$ & 86.07 & 86.40 \\
\hline Grand mean & 4.21 & 3.94 & 37.19 & 36.12 & 86.35 & 86.25 \\
\hline LSD (SD) & 0.34 & 0.24 & ns & 1.48 & $\mathrm{~ns}$ & ns \\
\hline $\operatorname{LSD}(\mathrm{C})$ & 0.32 & 0.28 & 1.74 & 1.56 & $\mathrm{~ns}$ & $\mathrm{~ns}$ \\
\hline SDxC interaction & $\mathrm{ns}$ & $\mathrm{ns}$ & ns & 2.71 & ns & ns \\
\hline C.V. $\%$ & 7.59 & 7.12 & 4.73 & 4.37 & 1.43 & 1.83 \\
\hline
\end{tabular}

* Means in each column followed by the same letter are not significantly different $(\mathrm{p}<0.05)$. SD: sowing date, C: cultivar

\section{Conclusion}

As a result of the research, seed cotton yield, plant height, number of bolls per plant, seed cotton weight and seed index decreased with delayed sowing while the number of days from sowing to boll opening and fiber fineness values increased. The number of fruiting branches per plant, ginning outturn, fiber length, fiber strength and fiber uniformity ratio were not affected by different sowing dates.

When the cultivars were investigated according to sowing dates, Stoneville 468 for seed cotton yield and number of days to open bolls; Stoneville 468 and BA 119 for number of bolls; DP-499 for plant height, number of fruiting branches, seed cotton weight, seed index and fiber strength; PG 2018 for ginning outturn and fiber fineness were promising. In addition, there was no significant difference between the cultivars in terms of fiber length and fiber uniformity ratio. 
The most important issue that cotton producers have focused on in cotton production is the seed cotton yield. In this study; cotton yield was found to be varied between $1440 \mathrm{~kg} \mathrm{ha}^{-1}$ and $4560 \mathrm{~kg} \mathrm{ha}^{-1}$. Autumn rainfall was early in the 2014 and 2015 cotton growing season. It is a major disadvantage for the trial years. Four cotton varieties used in the experiment; Stoneville 468 and BA 119 are medium early and have high adaptability. In addition, it was found that these varieties were not statistically different in terms of cotton yield. For this purpose, after wheat production under Harran Plain ecological conditions, Stoneville 468 and BA 119 cultivars may be preferred for second crop conditions.

Fiber properties were generally not affected by late sowing. However, a general decrease in fiber fineness values was observed. This is expected for late sowing. Therefore, for the development of cotton fibres and high seed cotton yield, sowing of cotton seeds must be completed immediately after the main crop harvest. For this purpose, stubble cultivation applications should be emphasized, early cultivars should be preferred and early cotton cultivars should be improvement for second crop cotton farming. In addition, since the vegetation period is short in the second crop cotton cultivation, studies on plant growth regulators should be carried out for the development of cotton plants.

\section{REFERENCES}

[1] Ali, H., Afzal, M. N., Ahmad, S., Muhammad, D. (2009): Effect of cultivars and sowing dates on yield and quality of Gossypium hirsutum L. Crop. - Journal of Food, Agriculture and Environment 7(3-4): 244-247.

[2] Anonymous (1989): User's Guide to MSTATC. An Analysis of Agronomic Research Experiments. - Michigan State University, USA.

[3] Anonymous (1997): High Volume Instruments (HVI) Catalog. - Costumer Information Service, No: 40, Volume: May, Sweden.

[4] Anonymous (2006): GAP Agricultural Research Institute, Soil Analysis Laboratory Results. - Sanliurfa, Turkey.

[5] Anonymous (2016): Official Record of Meteorology Directory. - Sanliurfa, Turkey.

[6] Anonymous (2019): Official record of Turkish Statistical Institute. http://www.tuik.gov.tr/bitkiselapp/bitkisel.zul (20 April 2019).

[7] Arshad, M., Wajid, A., Maqsood, M., Hussain, K., Aslam, M., Ibrahim, M. (2007): Response of growth, yield and quality of different cotton cultivars to sowing dates. Pakistan Journal of Agricultural Sciences 42(2): 208-212.

[8] Baran, F. O. (2013): The effects of different planting date on agronomical and technological properties in cotton (Gossypium hirsutum L.) under short season production conditions. - Adnan Menderes University, Graduate School of Natural and Applied Sciences, MSc Thesis, Aydın, Turkey (in Turkish).

[9] Barradas, G., Bellido, R. L. (2009): Genotype and planting date effects on cotton growth and production under South Portugal conditions, III. boll set percentage, boll location, yield and lint quality. - Journal of Food and Environment 7(2): 322-328.

[10] Bauer, P. J., Frederick, J. R., Bradow, J. M., Sadler, E. J., Evans, D. E. (2000): Canopy photosynthesis and fiber properties of normal and late planted cotton. - Agronomy Journal 92: 518-523.

[11] Bradow, J. M., Davidonis, G. H. (2000): Quantitation of fiber quality and the cotton production-processing interface: a physiologist's perspective. - The Journal of Cotton Science 4: 34-64. 
[12] Braunack, M., Bange, M., Johnston, D. (2012): Can planting date and cultivar selection improve resource use efficiency of cotton systems? - Field Crops Research 137: 1-11.

[13] Copur, O. (1999): A research on the effects of different planting dates on flowering, yield, yield components and earliness criteria of cotton (Gossypium hirsutum L.) at the Harran Plain conditions. - Harran University, Graduate School of Natural and Applied Sciences, PhD Thesis, Sanliurfa, Turkey (in Turkish).

[14] Copur, O. (2006): Determination of yield and yield components of some cotton cultivars in semi arid conditions. - Pakistan Journal of Biological Science 9(14): 2572-2578.

[15] Copur, O., Yuka, A. (2016): Determination of yield and yield components of cotton varieties (Gossypium hirsutum L.) grown as second crop after the wheat. - Yuzuncu Yil University, Journal of Agriculture Science 26(2): 245-253 (in Turkish).

[16] Copur, O., Gur, A., Özel, A., Oglakci, M. (2001): A research on the effects of different planting dates on the boll and fiber technological characteristics of cotton (Gossypium hirsutum L.) plant in the Harran Plain conditions-II. - Trakya University, Tekirdag Faculty of Agriculture, 4 ${ }^{\text {th }}$ National Field Crops Congress, 17-21 September 2001, Tekirdag, Turkey, pp. 181-186 (in Turkish).

[17] Dong, H., Li, W., Tang, W., Li, Z., Zhang, D., Niu, Y. (2006): Yield quality and leaf senescence of cotton grown at varying planting dates and plant densities in the Yellow River Valley of China. - Field Crops Research 98: 106-115.

[18] Du, X., Chen, B., Shen, T., Zhang, Y., Zhou, Z. (2015): Effect of cropping system on radiation use efficiency in double-cropped wheat-cotton. - Field Crop Research 170: 2131.

[19] Gormus, O., Yucel, C. (2002): Different planting date and potassium fertility effects on cotton yield and fiber properties in the Cukurova Region, Turkey. - Field Crops Research 98: 106-115.

[20] Gur, A., Copur, O., Ozel, A., Oglakci, M. (2001): A research on the effects of different planting dates on the yield, agronomic characteristics and earliness criteria of cotton (Gossypium hirsutum L.) plant in the Harran Plain conditions-I. - Trakya University Tekirdag, Faculty of Agriculture, $4^{\text {th }}$ National Field Crops Congress, 17-21 September 2001, Tekirdag, Turkey, pp. 175-180 (in Turkish).

[21] Iqbal, M., Ul-allah, S., Naeem, M., Hussain, M., Ijaz, M., Wasaya, A., Ahmad, M. Q. (2018): Reproductive development and seed cotton yield of Gossypium hirsutum L. affected by genotype and planting time. - Int. J. Aric. Biol. 20(7): 1591-1596.

[22] Jost, P. H., Cothren, J. T. (2000): Growth and yield comparisons of cotton in conventional and ultra narrow row spacing. - Crop Science 40: 430-435.

[23] Karademir, E., Karademir, C., Sezener, V. (2013): Adaptation of some cotton varieties for Diyarbakır Province conditions. - Selcuk University, Faculty of Agriculture, Proceeding of $10^{\text {th }}$ National Field Crops Congress, Vol. 2, 10-13 September 2013, Konya, Turkey, pp. 198-202 (in Turkish).

[24] Killi, F. (2005): Effect of early, normal and late planting dates on yield components of two cotton cultivars under irrigated conditions of Turkey. - Innovative Scientific Information \& Services Network Bioscience Research 2(1): 38-42.

[25] Killi, F., Bolek, Y. (2006): Timing of planting is crucial for cotton yield. - Acta Agriculturae Scandinavica Section B. Soil and Plant Science 56: 155-160.

[26] Ozbek, N., Eksi, İ., Erdogan, H. (2009): Improvement of early cotton cultivars by hybridization breeding method. - Mustafa Kemal University, $8^{\text {th }}$ National Field Crops Congress, 19-22 October 2009, Hatay, Turkey, pp. 747-751 (in Turkish).

[27] Pettigrew, W. T. (2002): Improved yield potential with an early planting cotton production system. - Agronomy Journal 94: 997-1003.

[28] Saeed, F., Kang, S. A., Amin, M. (2014): Performance of genotypes at different sowing dates on yield and quality traits in Gossypium hirsutum L. - Int. J. of Agric. and Crop Sci. 7(5): 274-278. 
[29] Saleem, M. F., Bilal, M. F., Anjum, S. A., Khan, H. Z., Sarwar, M., Farhad, W. (2014): Planting time and nutrition on cell membrane thermostability, bolls' retention and fibre traits in cotton. - The Journal of Animal \& Plant Sciences 24(3): 829-837.

[30] Soyler, D., Temel, N. (2007): Determination of suitable cotton (Gossypium hirsitum L.) varieties for growing as second crop after wheat in Hatay Province. - Ataturk University Faculty of Agriculture, $7^{\text {th }}$ National Field Crops Congress, Vol. 2, 25-27 June 2007, Erzurum, Turkey, pp. 736-739 (in Turkish).

[31] Usman, K., Ayatullah, K., Khan, N., Khan, S. (2016): Genotype-by-sowing date interaction effects on cotton yield and quality in irrigated condition of Dera Ismail Khan, Pakistan. - Pak. J. Bot. 1933-1944.

[32] Worley, S. Jr., Harmon, H. R., Harrel, D. C., Culp, T. W. (1976): Ontogenetic model of cotton yield. - Crop Science 16: 30-34.

[33] Wumbei, A. (2014): The effect of date of planting on the performance of promising cotton varieties. - Journal of Environment and Earth Science 4(4): 1-9. 